\title{
GEOLOGICAL SURVEY OF FINLAND RADIOCARBON MEASUREMENTS I
}

\author{
E. HYYPPÄ, V. HOFFRÉN, A. ISOLA \\ $\mathrm{C}^{14}$-laboratory, Geological Survey of Finland, Otaniemi, Finland
}

The $\mathrm{C}^{14}$-laboratory at the Geological Survey of Finland was started in October 1960 in order to determine ages of Quaternary objects. Only 11 samples that have been measured are ready to be published. Most samples in the following list have been measured many times in order to control the stability of the system and to make all necessary corrections. The $\mathrm{C}^{14}$-system includes two $\mathrm{CO}_{2}$-filled proportional counters. Until now the measurements have used only the first counter system. The second one is now ready for dating.

Pretreatment and purification: the samples are boiled in $2 \% \mathrm{NaOH}$ to remove humic acids. After filtering on fine copper gauze they are boiled in $20 \% \mathrm{H}_{2} \mathrm{SO}_{4}$ to remove carbonates, filtered, washed on the copper gauze and dried. After burning to $\mathrm{CO}_{2}$ the final radiochemical purification of the gas is done by the normal method in the $\mathrm{CaO}$-furnace. The often-discussed memory effect on the $\mathrm{CaO}$ is impossible in the furnace as constructed.

Specifications of the first counter system: the proportional counter is made of copper with a total volume of $1.2 \mathrm{~L}$ and an effective volume of $1 \mathrm{~L}$. The working pressure is $3 \mathrm{~atm}$ and the working voltage $6.6 \mathrm{kv}$. The length of the plateau, using cosmic radiation is $900 \mathrm{v}$, the plateau slope $0.8 \% / 100 \mathrm{v}$. The background (anthracite) 13.4 counts/min; the net counting rate for a modern sample (without any corrections for dead times in the electronic system) 17.6 counts $/ \mathrm{min}$. The counting rate of the cosmic radiation is 135 counts $/ \mathrm{min}$ at standard air pressure of $760 \mathrm{~mm} \mathrm{Hg}$. The iron shield around the counter has a thickness of $20 \mathrm{~cm}$.

As a modern sample we are using 50-yr-old pine (yr rings between 45$55 \mathrm{yr})$ from Vihti $\left(60^{\circ} 25^{\prime} \mathrm{N}\right.$ Lat, $21^{\circ} 21^{\prime} \mathrm{E}$ Long), not yet compared to any other modern standard. The mentioned $50 \mathrm{yr}$ are taken into account in the calculations of the ages. The value of $5570 \mathrm{yr}$ is used for the $\mathrm{C}^{14}$ half life. No measurements of $\mathrm{C}^{12} / \mathrm{C}^{13}$ ratios have been made.

Calculation of errors: although most of the samples in the following list have been measured many times, the errors (using a one-sigma-criterion) are calculated as if the samples were measured two or three times (a thousand minutes each time). This corresponds to our normal use now and in the future.

A more detailed description of our $\mathrm{C}^{14}$-laboratory will be published later.

\section{SAMPLE DESCRIPTIONS}

\section{GEOLOGIC SAMPLES}

\section{Su-2. Tanka-aapa, Vuotso, Finnish Lapland}

$8300 \pm 200$

Birch wood from Tanka-aapa peat bog, Vuotso $\left(68^{\circ} 07^{\prime} \mathrm{N}\right.$ Lat, $27^{\circ} 10^{\prime}$

E Long). Wood is from the basal layer of the peat bog at $255 \mathrm{~m}$ above sea- 
level. The pollen content (anal. A. Ignatius) of this horizon is $40 \%$ Pinus and $60 \%$ Betula. Coll. 1959 by E. Hyyppä, Geol. Survey of Finland from a handdug section. Comment: the region was probably deglaciated a little earlier during the Pre-Boreal period.

\section{Su-3. Lapaneva, Kihniö, Finland}

$8100 \pm 200$

Equisetum-Sphagnum-Carex peat at a depth of $2.1 \mathrm{~m}$ from a handdug section Lapaneva peat bog $163 \mathrm{~m}$ above sealevel, Kihniö $\left(62^{\circ} 15^{\prime} \mathrm{N}\right.$ Lat, $23^{\circ}$ 18’ E Long). Coll. 1958 by M. Salmi, Geol. Survey of Finland. Comment: according to pollen analysis (E. Uussaari) this level belongs to the Boreal pine maximum. Compare with dates Su-6 (from same section) and Su-5 (from an adjacent bog).

Su-4. Cagle's Mill Reservoir, Indiana, U.S.A.

Wood from silty layer overlain by till, Cagle's Mill Reservoir, SE 1/4 NE $1 / 4$ sec. 13, T 12 N, R 5 W, Putnam County, Indiana $\left(39^{\circ} 30^{\prime} \mathrm{N}\right.$ Lat, $86^{\circ} 53^{\prime}$ W Long). Coll. 1959 by the late Richard J. Lougee, Clark Univ. and Esa Hyyppä. Comment: the overlying till is believed to be of Kansan age (Wayne, 1958).

Su-5. Aitoneva, Kihnio, Finland

$4350 \pm 100$

Trunk of a pine tree embedded in Aitoneva peat bog, Kihniö $\left(62^{\circ} 15^{\prime} \mathrm{N}\right.$ Lat, $23^{\circ} 18^{\prime} \mathrm{E}$ Long) at a depth of 0.8 to $0.9 \mathrm{~m}$. Coll. 1958 by M. Salmi. Comment: according to pollen analysis (E. Uussaari) this level belongs to the Sub-Boreal period. Compare with dates $\mathrm{Su}-3$ and $\mathrm{Su}-6$.

Su-6. Lapaneva, Kihniö, Finland

$4100 \pm 100$

Sphagnum peat at a depth of 1.00 to $1.05 \mathrm{~m}$ Lapaneva peat bog $163 \mathrm{~m}$ above sealevel, Kihniö $\left(62^{\circ} 15^{\prime} \mathrm{N}\right.$ Lat, $23^{\circ} 18^{\prime} \mathrm{E}$ Long). Coll. 1958 by M. Salmi from a handdug section. Comment: according to pollen analysis (E. Uussaari) the sample belongs to the Sub-Boreal, at the beginning of the rise of the spruce-pollen curve. Compare with Su-3 and Su-6.

\section{Su-7. Ivalo, Finnish Lapland $\quad \mathbf{2 7 0 0} \pm \mathbf{9 0}$}

Birch wood from a peat layer in the eastern bank of the Ivalo river at Ivalo village $\left(68^{\circ} 38^{\prime} \mathrm{N}\right.$ Lat, $27^{\circ} 34^{\prime} \mathrm{E}$ Long). Coll. 1959 by E. Hyyppä from a handdug section. Sample is from the upper part of a layer of SphagnumCarex peat, $40 \mathrm{~cm}$ thick, overlain by 1.0 to $1.5 \mathrm{~m}$ of alluvial sand. The pollen content (anal. A. Ignatius) of the peat sample is 3\% Picea, $47 \%$ Pinus, $48 \%$ Betula and $2 \%$ Alnus. Comment: according to the date and on the basis of the stratigraphic sequence both the peat and the overlying alluvial sand should belong to the beginning of the Sub-Atlantic period.

\section{Su-8. Pölläkkälä, Karelian Isthmus, USSR $\quad 9850 \pm 300$}

Pine wood exposed in a railway cut at 14.30 to $14.45 \mathrm{~m}$ above sealevel in Pölläkkälä ( $60^{\circ} 57^{\prime} \mathrm{N}$ Lat, $29^{\circ} 46^{\prime} \mathrm{E}$ Long), $52 \mathrm{~km}$ ENE of Viipuri. Coll. 1935 by E. Hyyppä. The wood is from the basal part of a littoral peat deposit overlain by Ancylus clay mixed with sand. The clay is overlain by a deposit, $3.1 \mathrm{~m}$ thick, of littoral gravel and sand. Comment: the pollen content of the 
peat layer (35\% Pinus, 63\% Betula, and 2\% Alnus) represents the latter half of the Pre-Boreal period. Because the wood was not in position of growth, it probably slightly antedates the peat horizon studied (Hyyppä, 1942, p. 169) .

\section{Su-9. Panelia, Kiukainen, SW Finland}

$810 \pm 100$

Coarse detritus gyttja overlying a dugout canoe in a peat bog at $25.49 \mathrm{~m}$ above sealevel, Panelia, 34 km ENE from Rauma $\left(61^{\circ} 14^{\prime} \mathrm{N}\right.$ Lat, $28^{\circ} 08^{\prime} \mathrm{E}$ Long). Coll. 1958 by V. Valovirta, Geol. Survey of Finland. Comment: according to pollen analysis (E. Uussaari) sample belongs to the latter part of the Sub-Atlantic period.

\section{Su-10. Pello, Finnish Lapland}

Carex-Sphagnum peat from a depth of 1.2 to $1.3 \mathrm{~m}$, Pello $\left(66^{\circ} 46^{\prime} \mathrm{N}\right.$ Lat, 24 ${ }^{\circ}$ 04' E Long), along the Tornio River. The surface of the bog is at 84 $\mathrm{m}$ above sealevel. Coll. 1955 by E. Hyyppä from a handdug section. Comment: the pollen content (anal. K. Salminen) of this level is 9\% Picea, 30\% Pinus, 59\% Betula, and 2\% Alnus. The rise of the spruce-pollen curve starts at this level. The date is possibly too old and will be checked.

\section{Su-11. Koivisto, Karelian Isthmus, USSR $\quad \mathbf{5 6 2 0} \pm 140$}

Birch wood from the lower bar of a Littorina double shore bar in Koivisto, Karelian Isthmus, $47 \mathrm{~km} \mathrm{~S}$ of Viipuri $\left(60^{\circ} 21^{\prime} \mathrm{N}\right.$ Lat, $28^{\circ} 37^{\prime} \mathrm{E}$ Long $)$. Coll. 1936 by E. Hyyppä from a handdug section. Comment: date seems to indicate the latter part of the first Littorina transgression (LI), as also suggested by the pollen content (Hyyppä, 1937, p. 161).

\section{Su-13. Vävarsbacka, Porvoo, S Finland}

$9600 \pm 350$

Detritus gyttja at $57 \mathrm{~m}$ above sealevel from the base of a peat bog $12 \mathrm{~km}$ NE of Porvoo $\left(60^{\circ} 30^{\prime} \mathrm{N}\right.$ Lat, $25^{\circ} 44^{\prime} \mathrm{E}$ Long). The pollen content (anal. K. Salminen) of the sample is $21 \%$ Pinus, $78 \%$ Betula, and 1\% Alnus. Coll. 1961 by E. Hyyppä from a handdug section. Comment: on the basis of pollen analysis sample ought to belong to the middle of the Pre-Boreal period. On the basis of the stratigraphic sequence and the diatom flora it appears the gyttja was deposited at the time immediately following isolation of the basin from the Yoldia I stage of the Baltic Sea (Hyyppä, 1937, p. 65).

\section{REFERENCES}

Hyyppä, Esa, 1937, Post-Glacial changes of shore line in South Finland: Bull. Comm. Géol. Finl. no. 120, p. 1-225.

Hyyppä, Esa, 1937, Post-Glacial changes of shore line in South Finland: Comm. Géol. Finl. Bull. no. 120, p. 1-225.

1942, Beiträge zur Kenntnis der Ladoga- und Ancylustransgression: C. R. Soc. Géol. Finl., no. 15, p. 137-177.

Wayne, William J., 1958, Early Pleistocene sediments in Indiana: Jour. Geol., v. 66, p. 8-15.

Unpublished report, Geological Survey of Finland (in the Archives of the Dept. of Surficial Deposits). 